\title{
Analisis Struktur, Perilaku dan Kinerja Pemasaran Kentang di Desa Erelembang Kecamatan Tombolopao Kabupaten Gowa
}

\author{
Ardi Rumallang;, Jumiati, Akbar dan Nadir \\ Universitas Muhammadiyah Makassar \\ Jl. Sultan Alauddin No. 259 Makassar \\ *Alamat korespondensi: ardi.rumallang@unismuh.ac.id
}

\begin{abstract}
Analysis of structure, behavior and marketing performance of potato commodity in Erelembang Village Tombolopao District Gowa Regency
\end{abstract}

The context of structure, market behavior and marketing performance of potatoes in Erelembang Village, Tombolopao District as one of the centers of potato production in Gowa Regency will have a significant impact on the formation of potato prices in Gowa Regency. This study examined the structure, market behavior and marketing performance of potatoes which has the potential to become one of the potato price-forming which in turn will determine the price of potatoes and the income that will be received by farmers. The purposes of this study were (1) to know and analyze the structure of the potato market, (2) to know and analyze market behavior, and (3) to know and analyze the marketing performance of potatoes in Erelembang Village, Tombolopao District, Gowa Regency. The research method used was a survey method. The sample was determined using snowball sampling technique. Data analysis technique used in this study was descriptive qualitative. The results showed that: (1) the market structure was qualitatively included in a perfectly competitive market; (2) market behavior formed three marketing channels namely Marketing I (producer - consumer), Marketing II (producer - collector trader - retailer trader consumer), Marketing III (producer - collector trader - wholesaler - retailer - consumer); and (3) marketing performance that received the most profit was Marketing III.

Keywords: Market behavior, Market performance, Marketing structure

\begin{abstract}
ABSTRAK
Konteks struktur, perilaku pasar dan kinerja pemasaran kentang di Desa Erelembang Kecamatan Tombolopao sebagai salah satu daerah sentra produksi kentang di Kabupaten Gowa akan membawa dampak signifikan terhadap pembentukan harga kentang di Kabupaten Gowa. Penelitian ini mengkaji struktur, perilaku pasar dan kinerja pemasaran kentang yang berpotensi menjadi salah satu pembentuk harga kentang yang pada gilirannya akan menentukan harga kentang dan pendapatan yang akan diterima oleh petani. Tujuan penelitian ini adalah untuk (1) mengetahui dan menganalisis struktur pasar kentang, (2) mengetahui dan menganalisis perilaku pasar, serta (3) mengetahui dan menganalisis kinerja pemasaran kentang di Desa Erelembang Kecamatan Tombolopao Kabupaten Gowa. Metode penelitian yang digunakan adalah metode survei. Penentuan sampel menggunakan teknik snowball sampling. Teknik analasis data pada penelitian ini menggunakan deskriptif kualitatif. Hasil penelitian menunjukkan bahwa: (1) struktur pasar (market structure) secara kualitatif termasuk pasar persaingan sempurna; (2) perilaku pasar membentuk tiga saluran pemasaran yaitu Pemasaran I (produsen - konsumen), Pemasaran II (Produsen - pedagang pengumpul - pedagang pengecer - konsumen), dan Pemasaran III (Produsen - pedagang pengumpul - pedagang besar - pedagang pengecer - konsumen); serta (3) kinerja pemasaran yang paling banyak memperoleh keuntungan yaitu pada Pemasaran III.
\end{abstract}

Kata Kunci: Kinerja pemasaran, Perilaku pasar, Struktur pasar 


\section{PENDAHULUAN}

Kentang merupakan salah satu produk hortikultura sayur-mayur yang sangat penting dan strategis kedudukannya sebagai sumber penyediaan kebutuhan pangan pokok (Rumallang, 2019). Pada umumnya petani kentang sudah melaksanakan usahatani terpadu untuk memperoleh produksi kentang yang tinggi sehingga dapat meningkatkan pendapatan petani. Namun demikian, untuk diperolehnya tingkat harga yang tinggi yang akan diterima oleh petani diperlukan proses pemasaran yang baik untuk menyalurkan hasil produksi petani tersebut.

Swastha dan Irawan (2001) dan Alma (2007) menyebutkan bahwa pemasaran pertanian khususnya hortikultura masih menjadi bagian yang lemah dalam aliran komoditas karena belum berjalan secara efisien. Pada kenyataannya di daerah tempat penelitian, harga kentang yang diterima petani masih berfluktuasi dan bervariasi. Hal ini diakibatkan salah satunya oleh masih terbatasnya pendistribusian kentang yang dilakukan oleh petani di Desa Erelembang kepada lembaga pemasaran melainkan umumnya dilakukan secara langsung kepada pihak pedagang pengumpul. Di dalam sistem pemasaran, fluktuasi harga pada produk pertanian menjadi permasalahan utama (Irawan, 2007). Selain masalah panjangnya rantai pemasaran, fluktuasi harga dapat terjadi karena produksi yang hanya terkonsentrasi di daerah tertentu, atau pola produksi yang tidak sesuai, serta fasilitas yang tidak memadai dimana fluktuasi harga ini seringkali mengakibatkan kerugian pada petani. Menurut Sinaga dkk. (2014), proses pemasaran saat ini tidak hanya mendistribusikan barang sampai ke tangan konsumen saja, melainkan diperlukan koordinasi serta kolaborasi diantara lembaga pemasaran, agar produk mampu didistribusikan tepat waktu, jumlah, tempat, serta kepemilikan.

Kasus pada petani kentang di Pangalengan, Jawa Barat adalah petani masih tergantung pada keberadaan bandar sebagai lembaga pemasaran untuk menampung hasil panen mereka (Sinaga dkk., 2014). Dengan kondisi pemasaran tersebut mengakibatkan petani sulit meningkatkan pendapatan serta kesejahteraan, posisi tawar petani lemah dalam menentukan harga di pasar, serta sebagian pelaku saja yang mendapatkan marjin pemasaran yang lebih tinggi. Lebih jauh disarikan oleh Sinaga dkk. (2014) bahwa beberapa hal lain yang berpengaruh terhadap harga kentang tersebut diantaranya adalah akses informasi harga yang terbatas, keterikatan dengan bandar (pedagang pengumpul), teknologi yang digunakan masih sederhana, peranan kelompok tani yang belum maksimal, dan akses permodalan yang terbatas. Demikian juga bahwa struktur pasar dan besarnya marjin pemasaran akan memengaruhi tinggi rendahnya harga yang diterima petani sehingga struktur pasar dan penyebab tingginya marjin pemasaran ini harus diketahui untuk dapat meningkatkan sistem pemasaran. Penelitian ini bertujuan untuk menganalisis struktur, perilaku, dan kinerja pasar kentang di di Desa Erelembang Kecamatan Tombolopao Kabupaten Gowa.

Struktur, perilaku, dan kinerja pasar merupakan pendekatan yang dilakukan untuk memecahkan permasalahan khususnya dalam pemasaran produk pertanian (Sinaga dkk., 2014). Permasalahan yang berkaitan dengan pemasaran termasuk margin pemasaran yang tinggi, fluktuasi harga, risiko produk pertanian segardan pengolahan produk pertanian segar yang masih rendah. Struktur pasar secara sederhana merupakan kumpulan berbagai faktor yang mempengaruhi tingkat kompetensi di pasar (Rahayu, 2013).

Beberapa faktor yang menentukan struktur pasar adalah jumlah penjual dan pembeli, pangsa pasar, tingkat penguasaan teknologi, elastisitas permintaan terhadap suatu produk, lokasi, hambatan masuk pasar, dan tingkat efisiensi. Dua tipe struktur pasar utama adalah persaingan sempurna dan pasar persaingan tidak sempurna (Beierlein \& Woolverton, 1996). Struktur pasar ini akan memengaruhi kemampuan produsen atau pedagang dalam pembentukan harga. Produsen atau pedagang tidak mempunyai kekuatan untuk memengaruhi harga pada pasar persaingan sempurna (bertindak sebagai price taker) berbeda dengan ketika struktur pasarnya persaingan tidak sempurna dimana produsen atau pedagang dapat memengaruhi harga (bertindak sebagai pembentuk/price maker). Rahayu (2013) menyebutkan hasil beberapa studi menunjukkan bahwa struktur pasar komoditas pertanian tidak sempurna sehingga pedagang mempunyai kekuatan untuk memengaruhi harga pasar.

Perilaku Pasar merupakan tindakantindakan individu yang melibatkan pembelian penggunaan barang dan jasa termasuk proses pengambilan keputusan yang mendahului dan menentukan tindakan-tindakan tersebut sebagai pengalaman dengan produk, pelayanan dari sumber lainnya (Peter, 2014). Berkaitan dengan pemasaran, Sinaga dkk. (2014) menyebutkan bahwa perilaku pasar merupakan aktivitas yang dilakukan dalam pasar yang melibatkan fungsi-fungsi pemasaran seperti fungsi pertukaran, fisik, dan fasilitas. Perilaku pasar ini merupakan pola tingkah laku 
lembaga-lembaga pemasaran dalam struktur pasar tertentu yang meliputi kegiatan pembelian dan penjualan, penentuan dan pembentukan harga, kerjasama lembaga pemasaran, serta praktek fungsi pemasaran (Dahl \& Hammond, 1977). Suatu produk harus memiliki keunggulan dari produk-produk yang lain baik dari segi kualitas, desain, bentuk, ukuran, kemasan, pelayanan, garansi, dan rasa agar dapat menarik minat konsumen untuk mencoba dan membeli produk tersebut (Thamrin, 2014). Sementara itu, perilaku petani dalam sektor pertanian disebutkan jarang melakukan sortasi, grading, pengemasan ataupun perlakuan lain yang mengakibatkan harga yang diterima petani lebih kecil (Sinaga dkk., 2014). Dari segi pembeli, perilaku pembelian konsumen dipengaruhi oleh faktor-faktor budaya, sosial, karakteristik pribadi, dan psikologis pembeli (Kotler, 1999).

Kinerja pemasaran merupakan ukuran prestasi yang diperoleh dari aktifitas proses pemasaran secara menyeluruh dari sebuah perusahaan atau organisasi. Menurut Dahl dan Hammond (1977), kinerja pasar adalah keadaan sebagai akibat dari struktur dan perilaku pasar yang ditunjukkan dengan harga, biaya, dan volume produksi yang pada akhirnya dapat memberikan penilaian baik atau tidaknya suatu sistem pemasaran. Drucker (1995) dan Ferdinand (2000) menyatakan bahwa kinerja pemasaran merupakan faktor yang seringkali digunakan untuk mengukur dampak dari strategi yang diterapkan perusahaan dimana kinerja pemasaran yang baik dinyatakan dalam tiga besaran utama nilai, yaitu nilai penjualan, pertumbuhan penjualan, dan porsi pasar. Voss dan Voss (2000) mengemukakan bahwa kinerja pemasaran dapat dinyatakan berdasarkan volume penjualan, tingkat pertumbuhan penjualan, serta tingkat pertumbuhan pelanggan.

Ukuran kinerja pemasaran dapat diperoleh melalui aktivitas fungsi pemasaran. Pengukuran ini lebih rasional dibandingkan melalui pendekatan akuntansi sebab terkait langsung dengan aktivitas dari fungsi pemasaran tersebut. Beberapa indikator yang digunakan dalam menilai kinerja pemasaran adalah volume penjualan, pertumbuhan pelanggan, dan kemampulabaan (Ferdinand, 2000). Volume penjualan adalah volume penjualan dari produk perusahaan. Pertumbuhan pelanggan adalah tingkat pertumbuhan pelanggan perusahaan. Kemampulabaan adalah besarnya keuntungan yang diperoleh oleh perusahaan. Sementara itu, Zhou (2005) menggunakan pertumbuhan penjulan, tingkat profit, return on invesment, dan marketshare untuk mengukur kinerja pemasaran. Wahyono
(2002) menjelaskan bahwa pertumbuhan penjualan akan bergantung pada berapa jumlah pelanggan yang telah diketahui tingkat konsumsi rata-ratanya yang bersifat tetap. Nilai penjualan menunjukkan berapa rupiah atau berapa unit produk yang berhasil dijual oleh perusahaan kepada konsumen atau pelanggan. Semakin tinggi nilai penjualan mengindikasikan semakin banyak produk yang berhasil dijual oleh perusahaan. Hasil penelitian yang dilakukan oleh Li (2000) menunjukkan adanya pengaruh positif antara keunggulan bersaing dengan kinerja yang diukur melalui volume penjualan, tingkat keuntungan, pangsa pasar, dan return on investment.

\section{BAHAN DAN METODE}

\section{Lokasi Penelitian}

Penelitian dilaksanakan di Desa Erelembang Kecamatan Tombolopao Kabupaten Gowa. Lokasi ini dipilih karena merupakan daerah penghasil kentang yang paling banyak melakukan penjualan kentang baik skala lokal maupun skala regional.

\section{Populasi dan Sampel}

Populasi dan sampel dalam penelitian ini adalah petani kentang, pedagang pengumpul, pedagang besar dan pedagang pengecer serta pihakpihak yang terlibat langsung dengan pemasaran kentang. Sampel pada penelitian ini dengan rincian petani kentang 30 orang. Penentuan sampel pedagang kentang dilakukan dengan teknik snowball sampling.

\section{Sumber dan Teknik Pengumpulan Data}

Data yang digunakan dalam penelitian ini adalah data sekunder yang dipublikasikan oleh Badan Pusat Statistik (BPS), instansi pemerintah terkait lainnya, dan data primer yang diperoleh langsung dari responden. Teknik pengumpulan data yang gunakan adalah Focus Group Discussion (FGD), teknik wawancara dan dokumentasi berupa pedoman wawancara mendalam kepada responden dan pedagang dan foto-foto di lokasi penelitian.

\section{Analisa Data}

Untuk menganalisa struktur, perilaku dan kinerja pemasaran maka dilakukan analisis deskriptif kualitatif yaitu menjelaskan secara mendalam dan terperinci tentang struktur, perilaku dan kinerja pemasaran kentang di wilayah penelitian. Lebih lanjut analisis data dilakukan dengan analisis saluran pemasaran, analisis struktur pasar (konsentrasi pasar dan hambatan keluar masuk pasar), analisis perilaku 
pasar, dan analisis kinerja pasar (farmer share dan pemikiran operasional penelitian yang dilakukan marjin pemasaran). Secara umum kerangka disajikan pada Gambar 1.

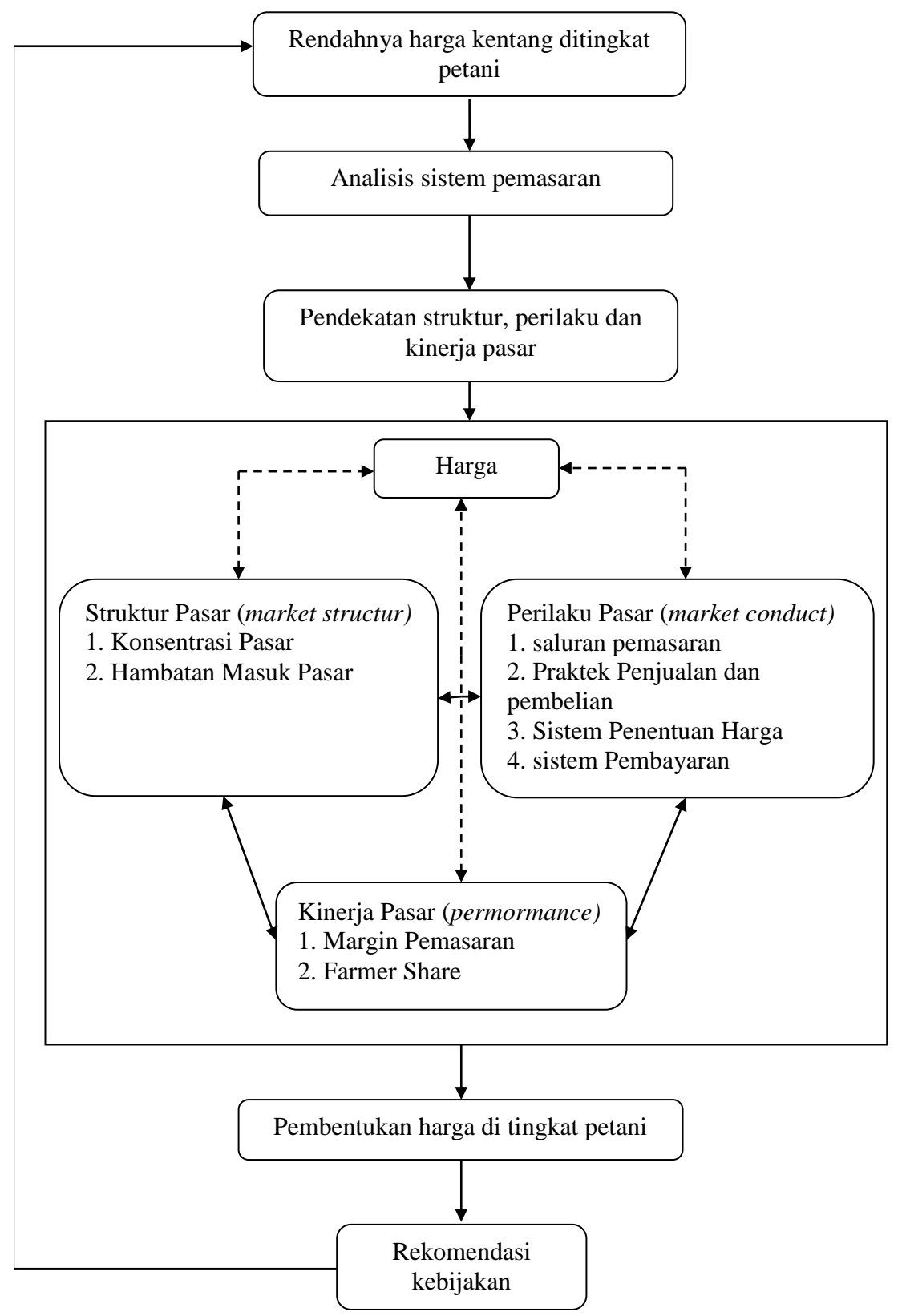

Gambar 1. Kerangka pemikiran operasional

\section{HASIL DAN PEMBAHASAN}

\section{Analisis Deskriptif Struktur Pasar Kentang}

Struktur pasar adalah penggolongan produsen kepada beberapa bentuk pasar berdasarkan pada ciri-ciri seperti jenis produk yang dihasilkan, banyaknya produsen, mudah tidaknya keluar atau masuk ke dalam pasar. Pada analisa ekonomi dibedakan menjadi pasar persaingan sempurna dan pasar persaingan tidak sempurna (monopoli, oligopoli, monopolistik, monopsoni, dan oligopsoni). Semua masyarakat di Desa Erelembang yang melakukan usahatani kentang merupakan penghasil atau produsen kentang. Jumlah petani kentang di Desa Erelembang sebanyak 510 orang yang setiap tahunnya melakukan usahatani kentang. Pedagang pengumpul di Desa Erelembang pada saat dilakukan penelitian sebanyak 30 orang.

\section{Hambatan Keluar Masuk Pasar}

Hambatan keluar masuk pasar merupakan adanya kebebasan atau batasan bagi setiap orang untuk ikut dalam kegiatan pemasaran di suatu wilayah tertentu. Dari hasil penelitian yang 
dilakukan di Desa Erelembang terdapat kebebasan pedagang dari dalam maupun dari luar desa yang bisa masuk pasar. Hal ini disebabkan karena para petani tidak memiliki keterikatan pada para pedagang, petani bebas menjual kentangnya ke pedagang yang mereka sukai. Hambatan keluar masuk pasar ini tidak terjadi dalam pemasaran kentang karena dilokasi penelitian terdapat banyak produsen dan pembeli, barang yang diperjual belikan bersifat homogen atau sejenis, produsen atau penjual bersifat mengambil harga (price taker), posisi tawar pedagang atau konsumen sangat kuat, sensitif terhadap perubahan harga. Artinya bahwa pembeli mengetahui tingkat harga yang berlaku dan perubahan-perubahan $\mathrm{ke}$ atas harga tersebut. Dengan demikian, produsen tidak dapat menjual kentangnya dengan harga yang lain lebih tinggi daripada yang berlaku di pasar. Volume produksi setiap produsen hanya merupakan bagian yang kecil dari volume transaksi total di pasar. Dari penjelasan yang telah dikemukakan maka secara kualitatif struktur pasar kentang di Desa Erelembang, Kecamatan Tombolopao, Kabupaten Gowa menuju pada struktur pasar persaingan sempurna.

\section{Perilaku Pasar}

Perilaku pasar merupakan tingkah laku lembaga pemasaran yang menyesuaikan dengan struktur pasar yang terbentuk. Perilaku pasar kentang dapat dijelaskan dengan praktik penentuan harga kentang. Petani kentang di lokasi penelitian telah mengetahui informasi tentang harga kentang saat ingin menjual hasil panennya kepada para pedagang. Praktik penentuan harga kentang di Desa Erelembang petani dapat melakukan tawar menawar pada saat melakukan penjualan ke para pedagang yang pada saat itu ada pedagang yang menawarkan harga yang lebih tinggi dengan harga yang berlaku di pasar, dan petani juga bebas menjual kentang mereka ke pedagang yang menawarkan harga yang lebih tinggi, hal ini dikarenakan petani tidak memiliki keterikatan kepada para pedagang.

Hal lain yang unik pada pemasaran kentang di Desa Erelembang bahwa pada saat petani menjual hasil panennya dengan harga yang telah disepakati kedua belah pihak, pedagang tidak langsung membayar langsung kepada petani, akan tetapi pedagang membayar petani pada saat kentang yang dibeli dari petani itu setelah laku dijual kepada pedagang berikutnya. Dengan demikian, petani terkadang menerima pembayaran dari pedagang selama satu minggu bahkan ada yang sampai berbulan-bulan, bahkan ada kasus pedagang yang tidak memberikan pembayaran kepada petani.
Perilaku pedagang yang mengutang lama bahkan tidak membayar petani menjadikan petani mengevaluasi keberadaan pedagang tersebut untuk selanjutnya akan diberikan sanksi sosial oleh petani kentang bahwa pada musim panen berikutnya petani sepakat untuk tidak menjual produksi kentang mereka kepada pedagang yang merugikan petani kentang. Dari perilaku pasar kentang di lokasi penelitian, ada potensi pembentukan beberapa saluran pemasaran yang menjadi tempat para petani atau produsen memasarkan produksi dan hasil panen mereka.

\section{Saluran Pemasaran Kentang}

Saluran pemasaran kentang dianalisis secara deskriptif, yaitu dengan melihat aliran yang dilalui oleh lembaga-lembaga pemasaran yang ada dalam proses pemasaran hasil produksi kentang mulai dari petani hingga sampai ke konsumen. Dalam kasus pemasaran kentang di Desa Erelembang Kecamatan Tombolopao Kabupaten Gowa panjang pendeknya saluran pemasaran tidak berpengaruh pada harga yang akan diterima oleh petani sebagai produsen.

Dari hasil penelitian diketahui ada tiga jenis saluran pemasaran kentang, mulai dari produsen sampai ke konsumen. Saluran pemasaran I (Gambar 2) merupakan arus produksi yang terpendek yaitu petani kentang sebagai produsen langsung menjual kentangnya kepada konsumen tanpa melalui perantara. Pemasaran ini terjadi pada saat konsumen ada acara keluarga seperti hajatan, pernikahan, aqikah dan lain-lain. Dari tiga saluran pemasaran yang ada, maka saluran pemasaran I ini yang paling sedikit melakukan transaksi jual beli atau melakukan pemasaran kentang, karena konsumennya adalah masyarakat sekitar yang ada di lokasi penelitian yang tidak melakukan usahatani kentang. Harga kentang pada semua saluran pemasaran di tingkat produsen pada saat dilakukan penelitian relatif sama yaitu $\mathrm{Rp}$. $8.500,00 / \mathrm{kg}$.

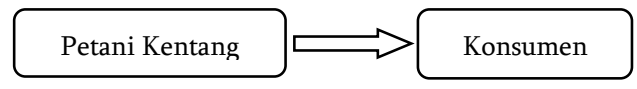

Gambar 2. Pemasaran I

Saluran pemasaran II (Gambar 3) yaitu petani kentang menjual kentangnya ke pedagang pengumpul kemudian pedagang pengumpul menjual kepada konsumen. Harga jual petani kepedagang pengumpul Rp. 8.500,00/kg, kemudian pedagang pengumpul menjual kekonsumen dengan harga Rp. $10.000,00 / \mathrm{kg}$ dan Rp.11.000,00/kg. Pada saluran pemasaran ini terdapat dua pasar yang dituju yaitu pasar sentral Malino yang bertempat di kecamatan 
Tinggimoncong sebagai tetangga kecamatan dimana dilakukan penelitian dan pasar Minasamaupa yang bertempat di ibu kota Kabupaten Gowa dan kota
Makassar. Pedagang pengumpul menjual di pasar Malino Rp.10.000,00/kg dan Rp. 11.000,00/kg di pasar Minasamaupa dan kota Makassar.

\section{Petani Kentang $\Rightarrow$ Pedagang Pengumpul $\Rightarrow$ Konsumen}

Gambar 3. Pemasaran II

Saluran pemasaran III (Gambar 4) konsumen dengan harga Rp.20.000,00 - Rp. merupakan saluran pemasaran yang terpanjang di lokasi penelitian yaitu petani menjual kentangnya ke pedagang pengumpul kemudian pedagang pengumpul menjualnya ke pedagang besar, selanjutnya pedagang besar menjual ke pedagang pengecer dan pedagang pengecer menjualnya ke konsumen. Pada saluran pemasaran ini petani menjual kentangnya kepadagang pengumpul dengan harga Rp. 8.500,00/kg, kemudian pedagang pengumpul menjual dengan harga Rp. 12.000,00/kg ke pedagang besar, pedagang besar menjual ke pedagang pengecer Rp. 17.000,00 - Rp. 20.000,00/kg, selanjutnya pedagang pengecer menjual ke $25.000,00 / \mathrm{kg}$. Pedagang besar ini berada di Kabupaten Enrekang Provinsi Sulawesi Selatan yang mengirim keberbagai daerah di Indonesia seperti Papua, Kendari, Kalimantan dan lain-lain. Harga jual pedagang besar kepedagang besar berbeda-beda sesuai dengan jarak dan biaya pemasaran yang dikeluarkan ke daerah yang akan dituju. Harga jual di daerah Papua, Kendari dan Kalimantan berbedabeda seperti di Kalimantan harga jual pedagang besar Rp. 20.000,00/kg, di Kendari dengan harga Rp. $15.000,00 / \mathrm{kg}$ dan di Papua mencapai Rp. $25.000,00 / \mathrm{kg}$.

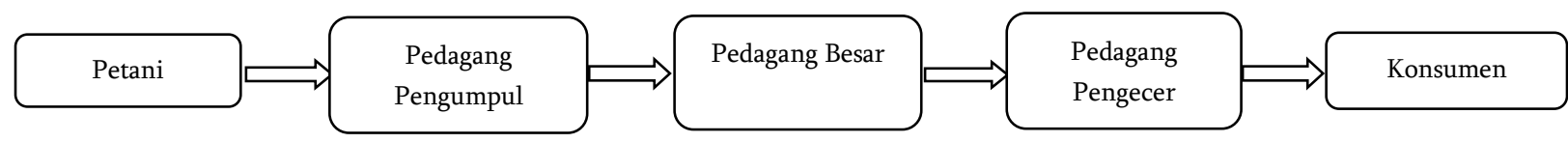

Gambar 4. Pemasaran III

Data pada Tabel 1 menunjukkan jumlah lembaga pemasaran yang terlibat dalam pemasaran kentang di lokasi penelitian. Lembaga pemasaran yang terlibat pada saluran pemasaran I tidak ada karena pada saluran ini petani kentang langsung menjual kentangnya kepada konsumen. Kemudian pada saluran II terdapat 27 orang pedagang pengumpul yang terlibat dalam melakukan pemasaran kentang di lokasi penelitian. Pedagang ini berasal dari desa tempat dilakukannya penelitian. Dari 27 orang pedagang pengumpul terdapat 14 orang pedagang yang memasarkan kentang di pasar sentral malino yang semua terdiri dari golongan perempuan atau ibu-ibu. Sementara itu, 13 orang pedagang pengumpul melakukan pemasaran kentang di pasar Minasamaupa dan kota Makassar. Pada saluran pemasaran III terdapat tiga orang pedagang pengumpul yang bertempat di desa tempat penelitian, dua orang pedagang besar bertempat di Kabupaten Enrekang dan lima orang pedagang pengecer masing-masing dua orang di Kendari, dua orang di Kalimantan dan satu orang di Papua.

\section{Kinerja Pemasaran}

Kinerja pasar adalah hasil akhir yang dicapai sebagai akibat dari penyesuaian pasar yang dilakukan oleh lembaga pemasaran (Dahl \& Hammond, 1977). Kinerja pemasaran atau disebut juga keragaan pasar timbul akibat adanya struktur pasar dan perilaku pasar biasanya terkait dengan harga, biaya dan volume produksi yang menentukan suatu sistem pemasaran. Kinerja pasar dapat diketahui dari tingkat harga yang terbentuk di pasar serta penyebaran harga di tingkat produsen sampai konsumen.

Kinerja pemasaran memperlihatkan selisih harga dari setiap lembaga pemasaran kentang yang sekaligus diterima oleh setiap lembaga pemasaran. Selisih harga ini dalam konsep pemasaran disebut margin pemasaran. Margin pemasaran kentang di lokasi penelitian dari setiap saluran pemasaran berbeda-beda. Untuk lebih jelasnya margin pemasaran kentang di Desa Erelembang Kecamatan Tombolopao Kabupaten Gowa dapat dilihat pada Tabel 2. 
Tabel 1. Jumlah lembaga pemasaran yang terlibat dalam pemasaran kentang di lokasi penelitian

\begin{tabular}{lccc}
\hline Lembaga pemasaran & Pedagang pengumpul (orang) & Pedagang besar (orang) & Pedagang pengecer (orang) \\
\hline Pemasaran I & 0 & & \\
Pesamasaran II & 27 & & 5 \\
Pemasaran III & 3 & 2 & 5 \\
\hline Jumlah & 30 & 2 & \\
\hline
\end{tabular}

Data Primer Setelah Diolah, 2019

Tabel 2. Margin pemasaran kentang di Desa Erelembang Kecamatan Tombolopao Kabupaten Gowa

\begin{tabular}{|c|c|c|c|}
\hline Saluran pemasaran & Harga beli $(\mathrm{Rp} / \mathrm{kg})$ & Harga jual $(\mathrm{Rp} / \mathrm{kg})$ & Margin (Rp/kg) \\
\hline \multicolumn{4}{|l|}{ Pemasaran $I$} \\
\hline Petani & - & 8.500 & 0 \\
\hline \multirow[t]{2}{*}{ Konsumen } & 8.500 & - & \\
\hline & Jumlah & & 0 \\
\hline \multicolumn{4}{|l|}{ Pemasaran II } \\
\hline Petani & - & 8.500 & - \\
\hline Pedagang Pengumpul & 8.500 & 10.000 & 1.500 \\
\hline \multirow[t]{2}{*}{ Konsumen } & 10.000 & - & - \\
\hline & Jumlah & & 1.500 \\
\hline \multicolumn{4}{|l|}{ Pemasaran III } \\
\hline Petani & - & 8.500 & - \\
\hline Pedagang Pengumpul & 8.500 & 12.000 & 3.500 \\
\hline pedagang Besar & 12.000 & 17.000 & 5.000 \\
\hline pedagang pengecer & 17.000 & 20.000 & 3.000 \\
\hline Konsumen & 20.000 & - & - \\
\hline \multicolumn{3}{|c|}{ Jumlah } & 11.500 \\
\hline
\end{tabular}

Data Primer Setelah Diolah, 2019

Data pada Tabel 2 menunjukkan bahwa saluran pemasaran III memperoleh total margin pemasaran kentang sebesar Rp. $11.500,00 / \mathrm{kg}$, yang diterima pedagang pengumpul Rp. $3.500,00 / \mathrm{kg}$, pedagang besar sebesar Rp. $5.000,00 / \mathrm{kg}$, dan pedagang pengecer mendapatkan Rp. 3.000,00/kg. Margin pemasaran kemudian saluran pemasaran II dengan margin pemasaran sebesar Rp. 1.500,00/kg. Sementara saluran pemasaran I tidak memiliki margin karena petani langsung menjual kentangnya kepada konsumen. Perbedaan margin yang diterima pada setiap saluran dan lembaga pemasaran disebabkan oleh biaya pemasaran yang dikeluarkan oleh setiap saluran dan lembaga pemasaran tersebut. Biaya pemasaran yang dimaksud seperti biaya transportasi, biaya bongkar muat dan biaya-biaya lain yang berhubungan langsung dengan pemasaran kentang.

\section{SIMPULAN}

Dari hasil penelitian yang telah dilakukan maka dapat disimpulkan sebagai berikut:

1. Secara kualitatif struktur pasar kentang di Desa Erelembang Kecamatan Tombolopao Kabupaten Gowa menuju kepada struktur pasar persaingan sempurna.

2. Perilaku pasar kentang membentuk tiga saluran Pemasaran yaitu Pemasaran I (produsen konsumen), Pemasaran II (Produsen - pedagang pengumpul - pedagang pengecer - konsumen), dan Pemasaran III (Produsen - pedagang pengumpul - pedagang besar - pedagang pengecer - konsumen).

3. Kinerja pemasaran yang paling banyak memperoleh keuntungan yaitu pada pemasaran III yaitu sebesar Rp. 11.500,00/kg. 


\section{DAFTAR PUSTAKA}

Alma, B. 2007. Manajemen Pemasaran dan Pemasaran Jasa. CV. Alfabeta. Bandung.

Beierlein, JG, and MW Woolverton. 1996. Agribusiness Marketing. Prentice Hall. New Jersey.

Dahl, DC, and JW Hammond. 1977. Market and Price Analysis. Mc. Graw Hill. New York.

Drucker, PF. 1995. Pengarntar Manajemen. Alih Bahasa R Hamzah. Pustaka Binaman Presssindo. Jakarta.

Ferdinand, A. 2000. Manajemen Pemasaran: Sebuah Pendekatan Strategy. Research Paper Series. No. $01 \quad$ Program Magister ManajemenUniversitas Diponegoro.

Irawan, B. 2007. Fluktuasi harga, transmisi harga, dan marjin pemasaran sayuran dan buah. Analisis Kebijakan Pertanian. 5(4): 358-373.

Li, LX. 2000. An analysis of sources of competitiveness and performance of chinese manufacturers, international journal of operation and production management. 20(3): 299-315.

Peter, JP. 2014. Perilaku Konsumen dan Strategi Pemasaran, Rencana, Strategi, Marketing. Salemba Empat. Jakarta.

Kotler, P. 1999. Manajemen Pemasaran Jilid 1: Analisis, Perencanaan, Implementasi, dan Pengendalian. Alih bahasa J Wasana. Erlangga. Jakarta.

Rahayu, ES. 2013. Analisis struktur pasar (market structure) jagung di Kabupaten Grobogan. Journal of Rural and Development. 4(1): 117.

Rumallang, A. 2019. Kajian bagi hasil dan pendapatan petani berbasis komoditi di Desa Erelembang Kecamatan Tombolopao Kabupaten Gowa. ZIRAA'AH. 44(3): 326336.

Sinaga, VR, A Fariyanti, dan N Tinaprilla. 2014. Analisis struktur, perilaku, dan kinerja pemasaran kentang Granola di Kecamatan Pangalengan, Kabupaten Bandung, Jawa Barat. Forum Agribisnis (Agribusiness Forum). 4(2): 101-120.

Swastha, B, dan Irawan. 2001. Manajemen Pemasaran Modern. Liberty. Yogyakarta.

Thamrin, A, dan F Tantri. 2016. Manajemen Pemasaran. PT Raja Grafindo Persada. Depok.

Voss, GB, and ZG Voss. 2000. Strategic orientation and firm performance in an artistic environment. Journal of Marketing. 64(1): 67-83.

Wahyono. 2002. Orientasi pasar dan inovasi: pengaruhnya terhadap kinerja pemasaran. Jurnal Sains Pemasaran Indonesia. 1(1): 2340.

Zhou, J, and R Elder. 2004. Audit quality and earnings management by seasoned equity offering firms. Asia-Pacific Journal of Accounting and Economics. 11(2): 95-120. 